\title{
EXCLUDED FROM EDUCATION AND WORK: PERCEPTIONS OF AT RISK YOUTH
}

\section{Margie Booyens, Elsa Crause}

\section{INTRODUCTION: BEING AT RISK}

"At risk" is a concept that reflects probability or likelihood, not certainty. Youth living in resource-poor rural areas and not in education, employment or training (NEET) have fewer opportunities to make the transition to the role requirements of adulthood - specifically to productive work. Risk factors such as exclusion from more than one key societal system, such as education and the economy, increase the chance of youth not being able to make a successful transition into adulthood. We argue that at risk youth and their environments should be specifically targeted for interventions by social service providers. The promotion of their inclusion in all spheres of community life - from work to active citizenship, building on the strengths and assets of young people, their families and the community - raises the chances of positive outcomes (Moore, 2006).

A rights-based South African National Youth Policy (Republic of South Africa, 2009), paired with public sector programmes targeting the inclusion of the youth, raises important questions about the extent to which individuals are aware and able to access these services, how at risk youth cope in their individual quests for inclusion in key sectors such as education and employment, and their expectations regarding government intervention.

Investigation is important as the number of at risk youth in South Africa is escalating and going beyond the realm of actions that individuals can take, emphasising the need for focused interventions on a national scale. The fact that in 2011 almost three quarters of unemployed people in South Africa were younger than 34 years bears testimony to this (Southern African Catholic Bishops' Conference, 2012). Qualitative studies such as the one reported in this article provide grounded insights to supplement and augment large-scale surveys on youth employment.

The purpose of this article is to shed light on the lives of at risk young people living in a rural setting and it focuses on:

- Findings about two key life transitions, namely the transition from school education to education for life and for work, and the transition to productive work;

- What young people expect regarding state interventions in the light of the rights-based policy context; and

- General pointers for the consideration of social service professionals in their work with at risk youth in rural areas.

In addition to eliciting common themes and societal patterns impacting on the youth in this country, this article aims to give a voice to the excluded.

It is fitting at this point to listen to the voice of one of the young people in the study. In response to a question about a typical day in his life, an unemployed 20-year-old male with Grade 11 said:

"Is baie boring, om dit so te stel. Eintlik het ek niks om te doen nie. Ek staan op, gaan eet, was, dan gaan ek miskien 'n movie kyk of so, speel miskien musiek, dis al. Sit miskien op die straat se hoeke. Dis al. Tot die aand toe. Ek wil miskien net uitgaan of 
net met die jeug rugby speel maar dit kan 'n mens nie doen nie. Hier's niks om te doen nie."

[It is very boring. Actually I have nothing to do. I get up, eat, wash, then I may watch a movie or so, perhaps play music, that's all. Maybe sit on street corners. That's all. Until the evening. I perhaps just want to go out or just play rugby with young people but one cannot do that. There's nothing to do here.]

The bleak monotony and pervasive sense of helplessness projected by these words demand interrogation. At stake is a cohort of excluded youth seeking active participation in the social, political and economic mainstream activities of the "South African Dream".

To illustrate the extent to which youth exclusion has become a national crisis rather than a personal problem in the life of individuals (from the classic book by C. Wright Mills published in 1959), the extent of youth exclusion is briefly presented and discussed. This is followed by an examination of the framework of laws and policies, which will confirm the legitimacy of youths' expectations of being able to access and enjoy appropriate education and employment in South Africa. Life transitions of learning for work and starting a working life are then briefly explored, followed by a consideration of perspectives on exclusion and development. After a description of the research methodology, the experiences and perceptions of the participants in relation to education, employment and government support are presented and analysed from a social exclusion theoretical perspective. Finally, based on the findings as well as the insights of the authors and suggestions from participants, selected considerations are offered to social service professionals (specifically, social workers, youth workers and community development workers) in relation to their work with at risk youth in rural areas.

\section{THE EXTENT OF YOUTH EXCLUSION}

The South African population is young, with those between birth and 34 years numbering 34303400 or $68.6 \%$ of the estimated total population of 49991300 (Statistics South Africa, 2010).

The right to a basic education enshrined in the Bill of Rights of the Constitution of South Africa (Republic of South Africa, 1996a) is manifesting in improved access to and uptake of basic education. The school system is, however, plagued with problems (Republic of South Africa, 2010). Some regard this as a national disaster (Bloch, 2009), with schools providing education "of such poor quality that they constitute a very significant obstacle to social and economic development" (Institute of Justice and Reconciliation (IJR), 2006 cited in Western Cape Youth Commission, 2008:83). The majority of mainly township and rural schools are dysfunctional (IJR, 2006 cited in Western Cape Youth Commission, 2008). High dropout and failure rates are evident with only about $39 \%$ of South Africa's youth obtaining a national certificate (Republic of South Africa, 2011).

The reality for rural children remains one of inequality, with poverty, hunger and transport costs (Western Cape Youth Commission, 2008), as well as factors such as female-headed households, teenage pregnancy and substance abuse (Branson \& Lam, 2008) taking their toll on both access to school and school completion rates.

Unemployment among the youth in South Africa, however one chooses to define it, is extensive and entrenched (Western Cape Youth Commission, 2008). While the unemployment rate of those with university degrees and matriculation certificates is $3 \%$ and $28 \%$ respectively, the percentage rises to over $60 \%$ of those without a Grade 12. Findings of a study involving 
2000 respondents, conducted in Gauteng, KwaZulu-Natal and the Western Cape, indicate that $39 \%$ of the respondents in the 14- to 20 -year-old age cohort who were no longer at school or involved in full-time study had never been formally employed or self-employed. This was applicable to $22 \%$ of the 21 - to 29 -year-olds and to $13 \%$ of the respondents in the 30 - to 35 year-old cohort (Western Cape Youth Commission, 2008:144).

Barriers to youth economic participation include the quality of their education, a mismatch of skills required by employers and those of job-seekers, the life skills of the job seeker (for example, some young people do not know how to look for a job) and the current economic climate in which insufficient jobs are being created. Added barriers relate to demographic factors: African, Indian and Coloured young people have lower access to employment than White youth; and urban youth have a greater chance of employment than those living in rural areas (Western Cape Youth Commission, 2008:51-52).

These levels of exclusion illustrate that the unemployment and unemployability of many young people are associated with structural factors, including South Africa's economic growth rate and the quality of the education system (Southern African Catholic Bishops' Conference, 2012). Thus the issue transcends the realm of the individual. Individual agency (actions) has to be supported by strong institutional interventions.

There is a need for investment by all sectors of society in the support of at risk youth through the inclusion and development of young people. The level and direction of interventions can be informed through the use of grounded qualitative investigations that offer a glimpse into the coping strategies and the expectations of at risk youth.

\section{THE RIGHTS-BASED POLICY AND LEGISLATIVE CONTEXT}

The Constitution (Republic of South Africa, 1996a) provides a vision of a non-discriminatory society in which human rights are acknowledged and respected. The legislative context illustrates the legitimacy of youths' expectations regarding appropriate education and employment, with basic rights protecting human dignity. Within this framework the government has introduced a range of policies, laws and programmes to promote the inclusion and development of young people between the ages of 14 and 35 years (Republic of South Africa, 2009), the most important of which are set out in Table 1. 


\section{TABLE 1}

YOUTH INCLUSION: POLICY AND LEGISLATIVE FRAMEWORK

\begin{tabular}{|c|c|c|}
\hline $\begin{array}{l}\text { CATE- } \\
\text { GORY }\end{array}$ & KEY EXAMPLES & $\begin{array}{l}\text { BRIEF DESCRIPTION } \\
\text { (reference) }\end{array}$ \\
\hline \multirow[t]{6}{*}{$\begin{array}{l}\text { Legisla } \\
\text { tion }\end{array}$} & $\begin{array}{l}\text { Constitution of the } \\
\text { Republic of South Africa } \\
\text { (Act No } 108 \text { of 1996) }\end{array}$ & $\begin{array}{l}\text { - Supreme law of the country } \\
\text { - Includes Bill of Rights } \\
\text { (Republic of South Africa, 1996a) }\end{array}$ \\
\hline & $\begin{array}{l}\text { South African Schools Act } \\
\text { (Act No } 84 \text { of 1996) }\end{array}$ & $\begin{array}{l}\text { Promotes access, quality and democratic governance in the } \\
\text { schooling system } \\
\text { - Makes schooling compulsory for children aged } 7 \text { to } 15 \\
\text { years/Grade } 7 \text { (Republic of South Africa, 1996b) }\end{array}$ \\
\hline & $\begin{array}{l}\text { National Skills } \\
\text { Development Act (Act No } \\
97 \text { of 1998) }\end{array}$ & $\begin{array}{l}\text { Makes provision for Sector Education and Training } \\
\text { Authorities (SETAs) (see below) } \\
\text { (Republic of South Africa, 1998a) }\end{array}$ \\
\hline & $\begin{array}{l}\text { Social Assistance Act (Act } \\
\text { No } 13 \text { of 2004) }\end{array}$ & $\begin{array}{l}\text { Establishes a social security and assistance framework } \\
\text { (Republic of South Africa, 2004) }\end{array}$ \\
\hline & $\begin{array}{l}\text { Further Education and } \\
\text { Training Colleges Act } \\
\text { (Act no } 16 \text { of 2006) }\end{array}$ & $\begin{array}{l}\text { - Provides for the establishment, governance and funding of } \\
\text { public FET colleges and related matters } \\
\text { (Republic of South Africa, 2006) }\end{array}$ \\
\hline & $\begin{array}{l}\text { National Youth } \\
\text { Development Agency Act } \\
\text { (Act No } 54 \text { of 2008) }\end{array}$ & $\begin{array}{l}\text { Makes provision for a National Youth Development Agency } \\
\text { which takes on the functions and responsibilities of the } \\
\text { Umsobomvu Fund and the National Youth Commission } \\
\text { (Republic of South Africa, 2008) }\end{array}$ \\
\hline \multirow{7}{*}{$\begin{array}{l}\text { Policies } \\
\text { and } \\
\text { pro- } \\
\text { gram- } \\
\text { mes }\end{array}$} & Cash transfers & $\begin{array}{l}\text { - Cash amounts administered through the government South } \\
\text { African Social Security Agency (SASSA) based on } \\
\text { eligibility criteria }\end{array}$ \\
\hline & $\begin{array}{l}\text { White Paper for Social } \\
\text { Welfare (1997) }\end{array}$ & $\begin{array}{l}\text { Sets out principles, guidelines, recommendations, proposed } \\
\text { policies and programmes for developmental social welfare } \\
\text { in South Africa (Republic of South Africa, 1997) }\end{array}$ \\
\hline & $\begin{array}{l}\text { Green Paper on National } \\
\text { Youth Service (NYS) } \\
(1998)\end{array}$ & $\begin{array}{l}\text { - Provides young people with opportunities to contribute to } \\
\text { their communities whilst developing their skills } \\
\text { (Republic of South Africa, 1998b) }\end{array}$ \\
\hline & $\begin{array}{l}\text { Sector Education and Trai- } \\
\text { ning Authorities (SETAs) } \\
\text { (Skills Development Act, } \\
\text { Act No } 97 \text { of 1998) }\end{array}$ & $\begin{array}{l}\text { Established in } 2000 \text { to manage skills development in South } \\
\text { Africa through learnerships (Republic of South Africa, } \\
\text { 1998a) }\end{array}$ \\
\hline & $\begin{array}{l}\text { Expanded Public Works } \\
\text { Programme (EPWP) }\end{array}$ & $\begin{array}{l}\text { - Aims to provide poverty and income relief through } \\
\text { temporary work for the unemployed to carry out socially } \\
\text { useful activities (Republic of South Africa, undated) }\end{array}$ \\
\hline & $\begin{array}{l}\text { Initiatives to improve } \\
\text { education access and } \\
\text { retention }\end{array}$ & $\begin{array}{l}\text { Initiatives include: } \\
\text { - No-fee schools in the poorest areas were introduced in } 2006 \\
\text { - National School Nutrition Programme (Republic of South } \\
\text { Africa, 2011) }\end{array}$ \\
\hline & $\begin{array}{l}\text { National Youth Policy } \\
\text { 2009-2014 (2009) }\end{array}$ & $\begin{array}{l}\text { - Builds on the National Youth Policy } 2000 \text { (1997) and the } \\
\text { National Youth Development Policy Framework 2002-2007 } \\
\text { (2002) } \\
\text { - Priority target groups include unemployed youth and } \\
\text { school-aged out-of-school youth (Republic of South Africa, } \\
\text { 2009:7) }\end{array}$ \\
\hline
\end{tabular}


The National Youth Policy of 2009 (Republic of South Africa, 2009) identifies "Youth at risk" as young people living with HIV or AIDS, heading households, in conflict with the law and abusing dependence-creating substances. Drawing on the definition of "at risk" in Moore (2006), the authors deliberately include two other priority groups, namely unemployed youth and school-aged out-of school youth, in the "at risk" category.

As illustrated in the section on the extent of youth exclusion, increasing numbers of young South Africans have yet to experience their rights and opportunities. This situation impacts heavily on their ability to make life transitions.

\section{LIFE TRANSITIONS: INTERRUPTION, SOCIAL EXCLUSION AND WAITHOOD}

Youth is a time in the life cycle during which key transitions need to be successfully negotiated as young people move from childhood to adulthood. Learning for work and life; going to work; forming families; and exercising citizenship are such transitions (Ansell, 2005; United Nations, 2007; World Bank, 2006). Transitions are pathways that young people take as they leave school and encounter different labour market, housing and family situations, and progress towards adulthood (Furlong \& Cartmel in Haralambos \& Holborn, 2008).

The interviews conducted with 19 participants of 18 to 21 years in Western Cape towns focused on five transitions that the World Bank has identified as pivotal (World Bank, 2006). Findings on two of the transitions are reported: learning for work and life, and starting a productive working life, both of which are key to reducing risky behaviour and crime through inclusion of the youth (Centre for Development and Enterprise, 2007).

Transitions to adulthood have become more varied and complex, and thus less predictable and of longer duration than in the past (Furlong \& Cartmel in Haralambos \& Holborn, 2008). Expectations of the direction of the transitions and the form they take are shaped by the social environment and the normative structure of expectations that individuals glean from their socialisation and their own interpretations. Failure to make these transitions successfully leads to dependence, financial limitations, frustration, self-doubt and feelings of anomie and alienation (Rankin, Simkins, Rule, Trope \& Bernstein, 2007). The concomitant vulnerability of individuals to succumb to behaviour that is counter-productive to establishing independence and self-actualisation, which are positively sanctioned by society, expands as unwanted pregnancies, substance abuse and criminal conduct become more likely outcomes than realisation of their expectations deriving from their human rights and the images of success that surround them.

The "no man's land" of waiting for an opportunity to get a bursary, to study, to be employed and so forth has been termed "waithood" (Dhillon \& Yousef, 2009). In "waithood" young people are unsure about where they are heading and do not have a clear sense of their future.

When contemplating factors impacting on successful transitioning, it is important to understand that youth agency is but one. MacDonald (2008:4) explains: "Each individual young person's transition is the outcome of individual agency informed by local sub-cultural and class cultural values and constrained by the contingencies of social structural opportunities." (our emphasis)

Salehi-Isfahani and Dhillon (2008) concur in the sense that they identify the root cause of youth exclusion lying in the institutions that mediate transitions to school, to work and to family formation. Outcomes in one sphere impact on other spheres, so failure in one transition may 
cause multiple failures resulting in escalating numbers of at risk youth as a consequence of exclusion.

If those working with young people do not adopt a holistic, multifaceted perspective, perhaps as a result of the inappropriate training of some practitioners, a myopic, "blame the victim" position may inadvertently be adopted. Studies such as the current one are thus important, serving to inform practitioners of common themes and societal patterns impacting on youth, particularly those who are economically and socially excluded.

\section{SOCIAL AND GEOGRAPHICAL EXCLUSION}

Social exclusion can be defined as "A process by which individuals or households experience deprivation, either of resources (such as income), or of social links to the wider community or society" (Marshall, 1998:212). It relates to processes (intentional and unintentional) that deprive individuals, groups and communities of resources and opportunities required for full participation in the social, economic and political activity of society (Burchardt, Le Grand \& Piachaud in Haralambos \& Holborn, 2008). This is a relational perspective of the term "social exclusion" (Rispel, Molomo \& Dumela, 2008).

In 2004 the Social Exclusion Unit (SEU) of the Local Government Improvement and Development Services in the United Kingdom reported on the following domains: income, employment, education, health, housing, transport, crime, social support/social capital and the impact of the neighbourhood (Bradshaw, Kemp, Baldwin \& Rowe, 2004). The SEU viewed the social exclusion of people or neighbourhoods in terms of being linked to, and mutually reinforcing, problems (Bradshaw et al., 2004:5).

A study by Gordon, Adelman, Ashworth, Bradshaw, Levitas, Middleton, Pantazis, Patsios, Payne, Townsend \& Williams (2000), at the time regarded as the most comprehensive survey of poverty and exclusion in Britain, identified the following criteria for measurement purposes:

- Impoverishment;

- Non-participation in the labour market;

- Lack of access to basic services, including access to basic services in the home such as power and water supplies, or outside the home, such as transport, shopping facilities and financial services;

- Exclusion from a range of social relations, viewed as:

- Non-participation in common social activities

- Social isolation

- A perceived lack of support in times of need

- Lack of civic engagement; and

- An inability to get "out and about" - geographical exclusion.

The above criteria underline the key role of affordable transport providing mobility for the poor and facilitating social inclusion by promoting access to key services and employment opportunities. Urry (undated) argues that being a full, active, participating member of society requires social capital within localities and that participation in turn involves mobility and transportation. We return to this point in the concluding section of the article. 
Young people who have left school without a Grade 12 certificate, who do not have access to non-academic skills training opportunities and who are neither self-employed nor gainfully employed are in a position of educational and employment exclusion. They are unable to develop their full potential, which in turn reduces their ability to contribute to their families and society (Republic of South Africa, 2009).

\section{PERSPECTIVES ON DEVELOPMENT}

Perspectives on development are changing continually. Recently development has been regarded as having the opportunity to live desirable lives (Sen, 1999). Central to such development is that people have the opportunity to lead healthy lives; have access to knowledge and learning; and contribute to, as well as share in, increases in prosperity. Sharing in prosperity means a range of things which go beyond aggregated wealth in monetary terms to a fair distribution of incomes, and fair access to key chances (health, knowledge and resources) for all groups in society. It also means eradicating poverty (Bown in Regan, 2006:42).

Development can be viewed from a macro as well as a micro perspective. Coetzee $(2001: 134)$ explains development from a micro, individual perspective as involving:

"... the removal of dehumanizing meaninglessness. Meaninglessness is experienced by individuals. It is, therefore, essential to focus on the individual in planning for development that will contribute to the establishment of a meaningful environment. The challenge is how to give voice to those who have been left out and to make their reality count."

Two important elements to consider in development are the need for people to determine their own goals of wellbeing and social inclusion, and the need for society to generate opportunities for people to achieve these outcomes - especially in a rights-based society.

Qualitative micro-level approaches take the needs, values and customs of people into account, as well as their own understanding of their circumstances (Davids, Theron \& Maphunye, 2009) and can be used for planning around youth development.

Against this background and in line with the purpose of the research, the questions to be addressed in the sections that follow are:

- How do young people who are early school leavers and not employed on a full-time basis, living in a rural environment, experience and cope with key life transitions related to education and employment?

- What do they expect with regard to government support in the light of the current rightsbased policy and legislative framework?

- What are the implications of the findings for the activities of practitioners?

\section{RESEARCH METHODOLOGY}

A qualitative study was undertaken, using a phenomenological method. A total of 19 young people between the ages of 15 and 24 years, early school leavers, not employed on a full-time basis and not married, were purposively selected by staff of the Advice and Development Centres (ADCs) in Botrivier, Ceres and Montagu, rural towns in the Western Cape, for voluntary participation in the study. A connection between the young person and the ADC was not a prerequisite. All were interviewed in depth (and tape-recorded), in Afrikaans, by one author. 
The interviews were on average 60 minutes in duration and conducted either at the ADC or in a private venue in the town concerned. The data collected were translated into English, analysed and grouped thematically, using the main research themes as the broad framework for analysis. Although the researcher had not had any previous contact with the participants, the verbal indication given by seven of the participants that the interview had been a positive experience and had helped them give thought to the future, is not only indicative of the extreme need for the mentoring of these young people, but also confirms a level of trustworthiness of the information provided. For the purposes of this article the focus is on findings related to education, employment and governmental support.

As mentioned, the potential value of this applied research lies in hearing the voices of young people who tend to be overlooked in youth research in South Africa, much of which is city based, problem focused and targeted at school-going young people (Brink, 2009). The identification of common themes across the experiences of different individuals has the potential to serve as pointers to social service professionals, assisting in the promotion of effective practice with young people.

With regard to ethical considerations, it was necessary to ensure that the participants were fully informed and took part voluntarily. On recruitment and at the start of each interview, participants were informed about the purpose of the study; they were reassured about the confidentiality of their disclosures and their anonymity with regard to the reporting of the findings; and they were made aware of their right to withdraw from the research process at any stage.

\section{THE RESEARCH PARTICIPANTS}

The 19 Coloured, Afrikaans-speaking participants lived in Botriver, Ceres and Montagu. The average age of the 11 young men and 8 young women was 20 years (rounded off). Four of the young women had one child that had been conceived after the participant left school. None of the young men reported being parents. No participant was head of the household in which he/she lived; the majority lived with their biological mothers; and in almost all cases their biological fathers were absent - living elsewhere, whereabouts unknown or deceased. The highest level of education achieved by the sample ranged from Grade 7 to Grade 11, with participants having left school between 2003 and 2009, on average three years previously.

\section{RESEARCH FINDINGS AND DISCUSSION}

The findings related to the participants' narratives of their experiences in education and employment, and their expectations of government support are now presented and analysed from a social exclusion perspective (Burchardt et al. in Haralambos \& Holborn, 2008). To protect the anonymity aspect of the research, the findings from the three towns are combined and the names of participants omitted.

\section{PARTICIPANTS AND FURTHER EDUCATION}

The 19 participants in the study form part of the 39\% of South African youth who do not complete high school (Republic of South Africa, 2011), a situation that impacts negatively on their educational path of learning for life and work, as well as their chances of starting a productive working life.

Three of the 19 participants had only achieved a Grade 7 certificate; one a Grade 8; six a Grade 9; and four a Grade 10 certificate. Five participants had a Grade 11 certificate - but had not gone on to successfully complete Grade 12 for reasons ranging from trying once and failing, 
Grade 12 not being offered at the Further Education and Training (FET) College where the young person had completed Grade 11, as result of too few registrations, problems at home that detracted from a focus on studies, financial reasons and a lack of parental encouragement to pursue their education. The following quotes illustrate some of these reasons:

"Baie van ons jongmense het die skool verlaat om hulle ouers te help werk."

[Many of our young people left school to work and help their parents.]

“... maar baie mense wat uit die skool uit is, is nie dom nie maar omstandighede of dinge wat in hulle lewe gebeur .. .baie van hulle is slim...het nie ouers wat hulle sê om skool toe te gaan nie ... het nie daai leierskap om te sê kom ons gaan verder."

[... but many people who have left school are not stupid. Circumstances or things happened in their lives ... many are clever ... do not have parents who tell them to go to school ... do not have guidance to go further.]

In most instances it had been the young people themselves who had decided not to return to school.

Learners in two of the three towns had to commute daily by bus to a high school in a neighbouring town. The government provided a free bus transport scheme in the one instance, but had withdrawn it from the other. Unemployed parents and guardians in the latter town would have experienced difficulty to find the money to keep their charges in the education system. These findings resonate with the views of the National Professional Teachers Organisation of South Africa (Naptosa) (South African Press Association, 2006) and Western Cape Youth Commission (2008), which identify, inter alia, poverty, unemployment and the difficulty of finding transport in rural areas as possible causes of the high drop-out rate from schools. The findings point to factors that interrupted the completion of schooling for the young people in the study being located at family, community and national levels (Bloch, 2009; Burchardt et al. in Haralambos \& Holborn, 2008; Soudien, 2007; Western Cape Youth Commission, 2008).

Regarding their plans at the time they left school, a few participants had left with no plan in mind and a few had immediately assumed a carer role within their households. The majority had planned to find employment, but not even one had found a full-time job.

"Toe ek die skool los dink ek ek gaan vir my 'n werk soek om vir haar [mother] te help in die huis want sy was die enigste een wat gewerk het. Maar tot vandag het ek niks gekry nie. Ek sit nogsteeds by die huis."

[When I left school, I thought I'd find a job to help her [mother] in the home, as she was the only one who worked. But up until today I have not found anything. I'm still sitting at home.]

Ten of the 19 participants had not accessed any educational courses or workshops since leaving school.

Thirteen of the 19 participants had thought about continuing their schooling via evening classes, a private college or a FET college. However, while they were clear on the potential value of obtaining a Grade 12 certificate, most did not have all the information they needed, nor a clearly thought-through plan. For example, participants who were considering taking evening classes locally seemed to have different - if any - information about registration dates for the following year and the availability of subjects. 
While funding for further studies was a barrier, few had accurate information about government bursaries available through the National Student Financial Aid Scheme (NSFAS) for studying at a FET College. One male participant, for example, wanted to become a boiler maker and believed he could get training in this trade at a FET College, but financial constraints stood in his way. He said: "Daar's nie finansies aan my kant" [There are no finances on my side]. He knew that financial assistance was available from the government, but did not know how to access a bursary: "Ek weet maar ek weet nie eintlik waar nie" [I know, but I don't know where].

None of the participants knew about education and employment opportunities available through the National Youth Service (NYS) or the Sector Education and Training Authority (SETA) learnerships (see Table 1).

Another finding highlighted the potential value for early school leavers of taking courses in caring - caring for senior citizens, for the sick, in the early childhood development (ECD) field and home care - which could open up pathways for further education and training and employment. The Extended Public Works Programme (EPWP) offers opportunities such as these (Republic of South Africa, undated). Four of the 19 participants - all young women knew about courses in caring and had taken a course or planned to enrol for one through an old age home or a FET college.

Those young people who had participated in different educational experiences since leaving school had been recruited by an ADC staff member, or had been connected to the opportunity through a relative or friend. This highlights the value of being part of social networks through which resources and opportunities are accessed (Hoppers, 2002:8).

While the agency of young people - including their motivation, attitude, choices and action - is clearly an essential facet of inclusion, young people also need access to information based on which they can make decisions and take action. An exacerbating factor was the inadequacy or absence of accessible, well marketed, clearly articulated vocational, non-academic pathways as alternatives for non-academically inclined youth. This points to the importance of the advocacy role of social service professionals, which is picked up in the final section of the article.

\section{PARTICIPANTS AND EMPLOYMENT}

The type of employment that 11 of the 19 young people in the study acquired was seasonal work - casual work on farms and in factories for a limited number of months in the year. The kinds of jobs others had had since leaving school included being a barman, a waitron, a painter, a tiler, a bricklayer's helper, a carer in an old age home, doing odd jobs, garden work, working in a bakery, employment as a loveLife groundbreaker, assisting at the local primary school when a teacher was absent, and working as a shop assistant. If the young people had had formal vocational skills training, some of these opportunities for employment could have become permanent.

Structural causes of unemployment, including the low economic growth rate of the country and the poor quality of the education and skills training system, combined with low levels of education, served to exclude most of the young people in the study from making a successful transition to a productive working life. Structural unemployment occurs when people are rendered unemployed because of capital-labour substitution or when there is a decline in demand in a particular industry. Causes of structural employment include a lack of the skills necessary to produce that for which there is a market (Black, 2002). This situation points to the need for more varied and accessible skills development courses at FET and other colleges 
and vocational centres. Advocacy by local communities and professionals for easier access to, and availability of, such types of training can make a positive difference.

Most of the young people in the study had connected with employment opportunities via their family and friendship networks, again illustrating the value of social networks (Hoppers, 2002). One young woman explained her route to employment at a fruit factory:

“My outjie se pa, hy is mos 'n voorman by X [name of factory], hy't vir my gesê hy gaan vir my kyk vir werk daar by $X$ [name of factory]. Toe het hy ' $n$ vorm gebring wat ek moet invul en toe het hy gesê maar hy gaan vir my by die sorteer tafel kyk vir werk ... toe't hy my daar laat inkom. Ek het net so twee weke gewag toe gaan werk ek by X", [name of factory].

[My boyfriend's father, he is a foreman at X [name of factory], he told me he would look out for a job for me at X [name of factory]. He then gave me a form which I had to complete and he then said he would keep an eye open for a job for me at the sorting table ... and he then brought me in at that level. I only waited for about two weeks then I then started working at $X$ [name of factory].]

The internet and printed news media were never mentioned as sources of information on employment opportunities, possibly because of their limited availability and the cost factor. Mention was made of the helpfulness of the library by participants in one of the three towns.

With regard to efforts made to find employment, many had written their curricula vitae (CVs) and submitted them to a potential place of employment through a relative or friend. Some had hiked to the town concerned to personally hand in their CVs, this being the only affordable means of transport for many. A combination of rural isolation, structural causes of unemployment, together with their level of education and lack of skills training meant that for most of the participants, their agency in trying to find a job amounted to nothing. One participant said that over the past year she had been to one nearby town nine to ten times, and to a second nearby town five to six times, seeking work at a new restaurant, a cleaning service, a supermarket, shoe shop and clothing store. She had not been successful.

One of the participants raised the age-old chicken-and-egg situation of some jobs requiring the applicant to have work experience, the reality being that many young people have never been employed. This participant had raised this problem at a local government meeting in relation to employment opportunities advertised by the local authority. He had been advised that young people should do voluntary work so as to gain experience which could then be listed on their CVs. This participant made his own views on volunteering very clear:

"In vandag se lewe kan ons nie meer vrywillige werk doen nie ... As ons kyk na die koste, die lewenskoste is hoog, alles is duur in die lewe. Ek moet vir my 'n lunch toebroodjie werk toe neem. Waar gaan die goed wat morê op daai broodjie moet kom, waar gaan dit vanaf kom? Die brood self? ... Jy wil daai opleiding so graag doen maar jy kan nie meer in 'n werk staan waar jy nie 'n inkomste kry nie...."

[In today's times we can no longer do voluntary work ... If we look at the costs, the cost of living is high, everything in life is expensive. I must take a sandwich to work for lunch. Where will the filling for that sandwich come from? The bread? ... You want that training so badly, but you can no longer take work from which you do not get an income.] 
These comments illustrate how family and community constraints impact on the choices young people can make. They highlight the need for careful identification of the types of basic support required by young people, particularly those from cash-strapped homes, that would enable them to volunteer in the public, business or not-for-profit sectors in order to gain work experience. It also illustrates the role short course skills training at vocational centres could play in raising employability (for example, as a waitron, sales person, tree pruner). Relevant too is the potential value of the government's NYS, SETA learnerships and the EPWP as mechanisms through which young people can learn and gain experience. The majority of the young people in the study were unable to explore these government-created opportunities as they had no knowledge of them.

Through the vision and support of a youth developer on the staff of a local ADC, three participants were working towards the establishment of a not-for-profit organisation (NPO) which, once operational and funded, could provide employment opportunities for these young people and others, in the context of offering a much-needed basic community health service. These three young people had taken, or were due to enrol for, additional short courses to equip them for employment in this field of service. These initiatives point to the need for, and the value of, youth workers who encourage "bottom-up" community development processes that promote the empowering active participation of young people.

Eight of the 19 young people had thought of starting their own business, but had no definite plans in this regard. There was a lack of finances to get going and a lack of information about financial and other types of assistance available from the government and other sources. This echoes the findings of a study conducted among one thousand 14- to 34-year-olds in the Western Cape in which a shortage of capital was regarded as the main reason for not starting a business (Western Cape Youth Commission, 2008).

While the majority of the 19 participants had set their sights on getting a full-time job, immediately or in the future, the employment aspirations of six did not extend beyond doing seasonal work in factories and on farms. It is possible that these low-level aspirations were partly the result of the influence of local subcultural and class cultural values (MacDonald, 2008:4). Other factors playing into the situation could include low self-esteem, ignorance on alternative opportunities and previous unsuccessful attempts to find a "better" job leaving the young person discouraged.

\section{PARTICIPANT'S EXPECTATIONS OF GOVERNMENT}

The resilience and hopefulness of the 19 young people, in spite of living in very adverse circumstances, becomes evident through the findings on their experiences and perceptions of government support - both current support and proposed.

Two of the four participants who had children received a monthly child-support benefit. The only other direct governmental assistance mentioned was food parcels received by a participant's family, as the need arose, from the Department of Social Development.

Every participant believed that government had to do something to support young people, like themselves, who were early school leavers and not gainfully employed.

Their suggestions on what government should do in relation to schooling are varied: offer programmes for early school leavers to enable them to complete Grade 12; look into why learners drop out of school; pay for bus transport to high school; assist when parents cannot afford school fees; and allow young people to continue attending school after turning 18 . While 
some of these suggestions indicate a lack of information, the fact that they relate to school education points to these young people perhaps not being comfortable with having left school when they did.

Fourteen of the 19 said the government needed to provide "work" or "jobs". Two participants focused on the need for government to provide training as well as job opportunities:

"Hulle moet meer werksgeleenthede of opleiding vir hulle gee waar hulle ook nie geld hoef te gee nie en dan kan hulle mos self aan die ou einde van die dag vir hulleself sorg."

[They should provide them with more job opportunities or training where they do not have to give money and then, at the end of the day, they can fend for themselves.]

"Die staat kan miskien 'n plek oopmaak soos hier in X [name of town] ... wat jongmense oplei vir werke, dan kan hulle hul CVs uitgooi en dis makliker om 'n werk te kry. Of hulle kan miskien 'n werkswinkel hier opsit, miskien kleremaak, dan kan hulle dit maak en verkoop ... .mense wat ons leer om dit te doen ... as ons suksesvol is dan kan ons ons eie besigheid ook oopmaak."

[The state can perhaps open a place like here in X [name of town] ... that trains young people, then they can distribute their CVs and it will be easier to get a job. Or they could perhaps establish a workshop, perhaps clothing manufacturing, then they can make and sell it ... people who teach us how to do it... if we are successful then we can open our own businesses.]

Financial independence seemed a preferred situation, as opposed to ongoing financial support from the government. Training was seen as a vital stepping stone towards this level of independence, which again confirms the importance of learnerships, FET colleges, and the availability to young people of information on opportunities.

Other forms of government provision suggested by the participants point to gaps in service delivery. Participants said that government should provide recreation opportunities for young people, a centre to meet and "do things", and guidance with regard to education and employment. One participant expressed these views most eloquently.

“... jongmense gaan ten gronde in $X$ [name of town] want ons jongmense verval in dwelms, hulle word alkohol verslaaf. Hoekom doen hulle daardie goed? Daar is geen ontspanningsplek vir ons kinders in X [name of town] nie."

[... young people are going to rack and ruin in X [name of town] because our young people resort to drugs, they become addicted to alcohol. Why do they do these things? There are no recreational facilities for our children in X [name of town]].

"Toe vra ek vir hulle [referring to the Municipal Council at a recent public meeting], maar hoekom ... hier's baie erwe, hulle kan mos 'n sentrum opsit en daar 'n juke box insit, games, dat ons die kinders kan entertain...."

[So I asked them [referring to the Municipal Council at a recent public meeting], but why ... there are many vacant plots of land, they can open a centre; put a juke box in it, games, so that we can entertain the children...]

"Bystand vir daai persone wat vroeg uit die skool is ... skep werk of eie besighede of aktiwiteite om verder te gaan met hulle lewens."

[Support for those people who are early school leavers ... create jobs or their own businesses or activities to help them get ahead in their lives.] 
Should the government provide a monthly grant to young people who, like themselves, had left school early and were not full-time employed? Thirteen of the 19 thought not.

"Nee, ek dink nie eintlik nie. Dit was hulle besluit [to leave school]. Dit was nie die government se besluit nie. Maar soos ek gesê het, hulle [referring to the government] kan werk skep...."

[No, I don't really think so. It was their decision [to leave school]. It was not the decision of the government. But as I said, they [referring to the government] can create jobs...]

Besides indicating a preference that government should enable the provision of jobs, other reasons for not supporting the idea of a grant included: grant recipients possibly becoming comfortable with their status and then not continuing their efforts to find employment; the belief that some young people would abuse the income; and the view that it would not be fair to give a state grant to healthy people. These views thus range from a negative view of fellow young people to a concern about equity.

While the majority wanted the opportunity to be economically active, four participants were in favour of receiving a government grant. Two of these four indicated that this would enable young people to start their own small business.

"Ek sal spaar om my [vrugte en groente] stalletjie oop te maak."

[I can save to open my [fruit and vegetable] stall.]

The other two said that a grant would enable young people to buy essentials, like personal hygiene goods.

"Want baie jong mense het mos nou nie geld om vir hulle dinge te koop soos onse jong meisies wat nou siek raak en [sanitary towels] moet gebruik en spray en tandepaste."

[Because many young people do not have money to buy things for themselves like our young women who become sick and must use [sanitary towels] and spray and toothpaste.]

Provision is made for Ward Committees, Youth Councils and Youth Forums at local government level through which the voices of young people can be heard and through which young people may choose to become active in local community affairs. With three exceptions, the 19 participants had not heard about these structures, yet in two of the three towns where the research was conducted a Youth Council or Youth Forum had been established.

Despite the bleak reality of their daily lives, these young people had not adopted a dependent, fatalistic position, as would have been indicated had they demanded unemployment benefits and focused more explicitly on demanding the fulfilment of their rights. They were clearly not willing to give up on themselves and the possibility of changed circumstances through their own agency. Facilitating their inclusion in society will, however, require structural changes in communities and society in addition to individual agency, an argument picked up in the final section of the article.

\section{REFLECTION}

Reflecting on all the above findings, the young people in the study seemed to be saying:

- Poverty and unemployment serve as constraints to our individual agency and as blocks to choices and opportunities; 
- We understand the potential value of education and training, but opportunities need to be made accessible, geographically and financially;

- We need alternatives to the academically-based curriculum;

- We need vocational training and short courses available in our communities;

- We do not want hand-outs. Give us jobs. We want to work and earn our own income;

- We need community-based alternatives to boredom, alcohol and drugs; and

- Listen to us and give us guidance.

It was telling that many participants experienced the interview very positively, as illustrated by the following quote:

"Ek voel nogal baie goed nou. Dis die eerste keer dat ek oor sulke dinge praat met iemand. Dis dingetjies wat ek altyd vir myself hou ... voel nogal baie goed. Ek't aan die begin van die jaar net eenkeer met Aunt X [a community worker] gepraat. Dis waar ek ook lekker gevoel het en sommer weer net opgehou het. Dit voel amper asof dis 'n berg van my skouers af."

[Now I feel really good. It is the first time that I have spoken to someone about such things. These are things that I always keep to myself ... feel very good. At the beginning of the year I spoke to Aunt X [a community worker] once. This is when I also felt good but then just stopped again. It almost feels as though a mountain has been lifted from my shoulders].

The young people in this study would value and benefit from a relationship with a mentor, an experienced and trusted person who could assist them to think through, develop and walk a realistic and appropriate route towards realising their educational aspirations, thereby negotiating more effectively the life transitions to learning for life and to work.

Current governmental policy and legislation are directed towards youth inclusion and youth development in South Africa, but this does not appear to be effective in rural areas, nor sufficiently available to the participants in this study. The findings suggest that the at risk participants in the study experience high levels of social exclusion and frustration.

In essence, key individual, family, community and societal factors driving the processes of exclusion of the young people in the study and serving to frustrate their successful transitions in the spheres of education and employment are:

- low levels of education;

- income poverty in the family;

- limited access to information on, and access to, a range of opportunities and resources, including those related to vocational training;

- a scarcity of job opportunities; and

- insufficient support and guidance.

The cost of exclusion is high, generating, inter alia, financial dependence, wasted human potential and in some instances young people attempting to meet their needs through anti-social behaviour, including substance abuse, gang membership and various forms of crime and violence. 
Based on the above findings, suggestions can be made about the type of support to which young people would be most likely to respond positively. These and other considerations follow.

\section{POINTERS FOR SOCIAL SERVICE PROFESSIONALS}

The sample was small and the study qualitative in nature, neither of which allows for generalisations. Nevertheless, the common issues that emerged from the 19 in-depth interviews and the insights of the authors allow for the framing of general pointers for the consideration of social service professionals in their work with at risk youth in rural areas.

It is critical that practitioners identify and analyse the range of factors, from past to present influences and from individual to global levels, impacting on levels of inclusion/exclusion of the particular young people with whom they are working, in their particular context. Developing an understanding of the 'bigger picture' enables a more accurate identification of the levels and strategic points at which interventions can be targeted to support youth along the route to adulthood, identifying, removing and preventing blocks to this process. Research done by oneself or others - should be a preferred approach through which a deeper understanding of the factors feeding into the situation is developed in order to plan and evaluate interventions from policy to programme/project levels in the public, private and voluntary sectors.

As alluded to by Coetzee (2001), it is critical for practitioners to listen, hear and respond to what young people are saying about their lived experiences and aspirations. Being afforded the time and space to speak and be heard was an experience many participants in the current study found empowering, encouraging, (indirectly) informative and offering some level of hope and control. Social service professionals can make a valuable contribution to youth finding direction and reducing the time they spend in "waithood" by supporting and counselling individual young people. Young people need opportunities to engage in self-reflective sessions, to clarify their longer-term aspirations, available resources, the individual action they can and need to take, and the issues that need to be addressed through advocacy and collective action, in partnership with others.

The findings point to social service practitioners needing to continue designing interventions to strengthen families and households. There is also a great deal of work to do in the school context to counter early school leaving by, for example, strengthening educator-parent/ guardian-learner relationships.

The findings point to the importance of a number of community-level interventions which can be facilitated by social service professionals in partnership with the youth and key role players in the public, private and voluntary sectors. Partnerships and networks are necessary for collective action.

Partnerships - a principle of the White Paper for Social Welfare (Republic of South Africa, 1997) - are important in a context of scarce resources, the need for a good flow of information about opportunities and resources, and the holistic nature of development. The social service practitioner needs to use her actions and interventions to identify and mobilise available resources into partnerships that can work with the youth to meet their needs. In rural areas this should include outreach to the farmers in the area who have resources like knowledge and skills in agriculture, which could be shared with aspiring young farmers and farm workers. 
Fewer youth will "fall through the cracks" if there are youth inclusive networks at community and broader levels, assessing and responding to the challenges faced by young people as they negotiate key life transitions. Youth Councils and Youth Forums are examples of the kinds of networks that can be established at local government level, offering young people channels through which to become active citizens, making their voices heard on education and employment and other relevant issues, thereby exercising and protecting their rights. Using an inclusive, democratic, bottom-up process (Swanepoel \& De Beer, 2006), social service professionals, for example youth workers and/or community development practitioners could facilitate the establishment and functioning of these structures which hold the promise of promoting the inclusion and development of young people at a local level.

The findings point to a number of other community-level interventions that social service practitioners can promote, in partnership with others:

- Increased opportunities for young people to develop social networks and promote their own inclusion in society through improved public transport services. The instrumental value for young people (and others) of associations, relationships and social networks, that is, social capital, within and between communities should not be underestimated. One route to building social capital is through the availability and use of public transport (Urry, undated). Public transport facilitates access to employment opportunities and to other key resources, but it also serves as a physical context in which relationships and networks between commuters are built, which can also provide access to opportunities. More research needs to be conducted in this regard, but the signs are that accessible public transport is a key to participation and social inclusion (Urry, undated);

- Recreational facilities and activities which offer young people attractive alternatives to boredom, alcohol and drug use, gang membership, crime and other destructive activities;

- Accessible, affordable educational and training opportunities, both formal and informal, as well as guidance and information on such opportunities located further afield, including FET Colleges, the EPWP, the SETA learnerships and the NYS. Together with the youth and other stakeholders, social service practitioners need to play a stronger advocacy role with regard to vocational paths for non-academically inclined youth. The kinds of vocations for which training is made available should depend on the aspirations of the youth balanced with the needs of prospective employers in the area, for example, farmers and those in the tourist industry;

- Opportunities to develop skills, gain experience and make a contribution to community development through voluntary work in the public, private and/or voluntary sectors - the proviso being that expenses incurred "on the job" are taken care of;

- The establishment of community centres where young people - and other residents - can access recreational activities, educational and especially vocational skills development programmes, information, support and guidance. Accessible counselling services and carefully planned mentorship programmes could operate from such centres; and

- An accessible, youth-friendly meeting place can also provide the opportunity and resources for young people to organise and mobilise themselves to advocate and take collective action around the issues about which they feel strongly. Social service professionals need to play a key role in this regard, helping young people to understand their personal experiences - their private troubles - as social or public issues, and to mobilise and take action collectively with other relevant groupings, to create a better deal 
for the youth in South Africa, particularly with regard to education and employment opportunities. This will require practitioners and young people alike to hold politicians and others accountable.

Young people are passionate and eager to make a difference. They are subjects, not objects, with their own ideas. When given opportunities, information and encouragement, they are able to act in their own interests (Ansell, 2005). But while individual agency (action) is key, young people also need to exercise their collective power to ensure that the rights-based, inclusive policy and legislative framework of the country is translated into programmes and projects which promote successful transitions into adulthood, minimising time spent in "waithood".

Keys factors for social service practitioners include investing in a better understanding of youth transitions in the region, bridging the gap between policy thinkers and development practitioners (Dhillon \& Yousef, 2009) and doing a great deal more research to identify innovative ways of advocating with and for young people, to promote and support their inclusion into the socio-economic systems of the community and country.

\section{REFERENCES}

ANSELL, N. 2005. Children, youth and development. Oxford: Routledge Perspectives on Development.

BLACK, J. 2002. Oxford dictionary of economics. Oxford: Oxford University Press.

BLOCH, G. 2009. The toxic mix. What's wrong with South Africa's schools and how to fix it. Cape Town: Tafelberg.

BRADSHAW, J., KEMP, P., BALDWIN, S. \& ROWE, A. 2004. The drivers of social exclusion: A review of the literature for the Social Exclusion Unit in the Breaking the Cycle series. London: Office of the Deputy Prime Minister.

BRANSON, N. \& LAM, D. 2008. Education: analysis of the NIDS Wave 1 Dataset. NIDS discussion paper no. 3. Republic of South Africa: The Presidency.

BRINK, P. 2009. Personal communication. Deputy Director: Social Research, Department of Social Development, Western Cape, 14 August 2009.

CENTRE FOR DEVELOPMENT AND ENTERPRISE 2007. Paths to employment. Challenges facing young people in accessing the job market. Report to the Conflict and Governance Facility (CAGE) and the Umsobomvu Youth Fund. Johannesburg: The Centre for Development and Enterprise.

COETZEE, J.K. 2001. A micro-foundation for development thinking. In: COETZEE, J.K., GRAAFF, J., HENDRICKS, F. \& WOOD, G. Development. Theory, policy, and practice. Oxford: Oxford University Press.

DAVIDS, I., THERON, F. \& MAPHUNYE, K.J. 2009. Participatory development in South Africa. A development management perspective $\left(2^{\text {nd }} \mathrm{ed}\right)$. Pretoria: Van Schaik Publishers.

DHILLON, N. \& YOUSEF, T. 2009. Inclusion: meeting the 100 million youth challenge. Washington: Middle East Youth Initiative.

GORDON, D., ADELMAN, L., ASHWORTH, K., BRADSHAW, J., LEVITAS, R., MIDDLETON, S., PANTAZIS, C., PATSIOS, D., PAYNE, S., TOWNSEND, P. \& WILliAMS, J. 2000. Poverty and social exclusion in Britain. York: Josepth Rowntree Foundation. 
HARALAMBOS, M. \& HOLBORN, M. 2008. Sociology. Themes and perspectives $\left(7^{\text {th }}\right.$ ed). London: HarperCollins Publishing Limited.

HOPPERS, W. 2002. Reconstructing youth development: a Southern African perspective. Africa Insight, 32(1):8-15.

MacDONALD, R. 2008. Disconnected youth? Social exclusion, the "Underclass" and economic marginality. Social Work and Society, 6(2):236-248.

MARSHALL, G. (ed) 1998. A Dictionary of Sociology. Oxford: Oxford University Press.

MILLS, C.W. 1959. The sociological imagination. New York: Oxford University Press.

MOORE, K.A. 2006. Defining the term “At risk”. Research-to-Results. Washington: Child Trends. [Online] Available: http://www.childtrends.org/Files//DefiningAtRisk\%5B1\%5D.pdf. [Accessed: 01/08/2011].

RANKIN, N., SIMKINS, C., RULE, S., TROPE, N. \& BERNSTEIN, A. 2007. Paths to employment. Challenges facing young people in accessing the job market. Johannesburg: The Centre for Development and Enterprise.

REGAN, C. (ed) 2006. 80:20. Development in an unequal world. Ireland: 80:20 Educating and Acting for a Better World.

REPUBLIC OF SOUTH AFRICA. 2011. Report on dropout and learner retention strategy to Portfolio Committee on Education. Pretoria: Department of Basic Education, June.

REPUBLIC OF SOUTH AFRICA. 2010. Millennium Development Goals Country Report 2010. [Online] Available: http://www.statssa.gov.za/news_archive/Docs/MDGR_2010.pdf. [Accessed: 15/02/2011].

REPUBLIC OF SOUTH AFRICA. undated. Expanded Public Works Programme five-year report 2004/05-2008/09. Pretoria: Dept. of Public Works.

REPUBLIC OF SOUTH AFRICA. 2009. National Youth Policy 2009-2014. [Online] Available: http://www.policy.org.za/polity/govdocs/policy/intro.html. [Accessed: 10/07/2009].

REPUBLIC OF SOUTH AFRICA. 2008. National Youth Development Agency Act No 54 of 2008. Pretoria: Government Printer.

REPUBLIC OF SOUTH AFRICA. 2006. Further Education and Training Colleges Act No 16 of 2006. Pretoria: Government Printer.

REPUBLIC OF SOUTH AFRICA. 2004. Social Assistance Act No 13 of 2004. Pretoria: Government Printer.

REPUBLIC OF SOUTH AFRICA. 1998a. Skills Development Act No 97 of 1998. Pretoria: Government Printer.

REPUBLIC OF SOUTH AFRICA. 1998b. Green Paper on National Youth Service. Pretoria: National Youth Commission in the Office of the Deputy President.

REPUBLIC OF SOUTH AFRICA. 1997. Ministry of Welfare and Population Development. White Paper for Social Welfare. Government Gazette, Vol. 386, No. 18166 (8 August). Pretoria: Government Printer.

REPUBLIC OF SOUTH AFRICA. 1996a. Constitution of the Republic of South Africa Act No 108 of 1996. Pretoria: Government Printer. 
REPUBLiC OF SOUTH AFRICA. 1996b. South African Schools Act No 84 of 1996. Pretoria: Government Printer.

RISPEL, L., MOLOMO, B. \& DUMELA, S. 2008. A South African case study on social exclusion. Pretoria: HSRC.

SALEHI-ISFAHANI, D. \& DHILLON, N. 2008. Stalled youth transitions in the Middle East. A framework for policy reform. Middle East Youth Initiative Working Paper, number 8, October. Brookings: Wolfensohn Center for Development and Dubai: Dubai School of Government.

SEN, A. 1999. Development as freedom. Oxford: Oxford University Press.

SOUDIEN, C. 2007. Youth identity in contemporary South Africa: race, culture and schooling. Claremont: New Africa Books.

SOUTH AFRICAN PRESS ASSOCIATION. 2006. Authorities urged to research high dropout rates from schools. Cape Times, 7 July.

SOUTHERN AFRICAN CATHOLIC BISHOPS' CONFERENCE. 2012. Youth unemployment: finding solutions. Briefing paper 289. Cape Town: Southern African Catholic Bishops' Conference Parliamentary Liaison Office.

STATISTICS SOUTH AFRICA. 2010. Mid-year population estimates, South Africa 2010, July 2010. Pretoria: StatsSA.

SWANEPOEL, H \& DE BEER, F. 2006. Community development. Breaking the cycle of poverty $\left(4^{\text {th }}\right.$ ed). Lansdowne: Juta and Co Ltd.

UNITED NATIONS. 2007. World Youth Report. Young people's transition to adulthood: Progress and challenges. New York: United Nations.

URRY, J. undated. Mobility and proximity. Lancaster: Department of Sociology, Lancaster University. [Online] Available: http://www.its.leeds.ac.uk/projects/mobilenetwork/downloads/ urry1stpaper.doc. [Accessed: 12/08/2006].

WESTERN CAPE YOUTH COMMISSION 2008. Western Cape Status of the Youth Report. Cape Town: Western Cape Youth Commission.

WORLD BANK 2006. World development report 2007. Development and the next generation. Washington DC: The World Bank.

Dr Margie G Booyens, Department of Social Development, University of Cape Town; Dr Elsa J Crause, Department of Sociology, University of the Free State, Qwaqwa Campus, South Africa. 